\title{
Singer v. Magnavox Co.: Delaware Imposes Restrictions on Freezeout Mergers
}

In Singer v. Magnavox Co. ${ }^{1}$ the Delaware Supreme Court ruled that majority shareholders of Delaware corporations violate a fiduciary duty to minority shareholders when they engineer a merger the sole purpose of which is to eliminate the minority shareholders from continued participation in the enterprise. In so holding, the court upset a longstanding trend in the Delaware law of corporate mergers and embarked on a new course of protection for minority shareholders involved in freezeout mergers. ${ }^{2}$

The difficulties caused by freezeout mergers have lately received much attention in the legal commentary, due in large part to the emergence of a particular type of freezeout transaction known as "going private."3 The term "going private" describes a situation in which the controlling insiders of an enterprise gain, or perhaps regain, sole equity ownership of the enterprise through some corporate device such as a "contrived" merger that forces the minority (public) shareholders to exchange their equity interests for cash. ${ }^{4}$ Freezeout mergers are employed in other situations as well.

1. 380 A.2d 969 (Del. 1977).

2. See text accompanying notes $12-30,46-48$ infra.

3. See, e.g., Bordon, Going Private-Old Tort, New Tort or No Tort?, 49 N.Y.U.L. Rev. 987 (1974); Brudney, A Note on "Going Private", 61 VA. L. Rev. 1019 (1975); Cary, Federalism and Corporate Law: Reflections Upon Delaware, 83 Y ALE L.J. 663 (1974); Jennings, Federalization of Corporation Law: Part Way or All the Way, 31 Bus. LAw. 991 (1976); O'Neal \& Janke, Utilizing Rule 10b-5 for Remedying Squeeze-Outs or Oppression of Minority Shareholders, 16 B.C. Indus. \& Com. L. Rev. 327 (1975); Note, The Second Circuit Adopts a Business Purpose Test for Going Private, 64 CALIF. L. REv. 1184 (1976) [hereinafter cited as Business Purpose Test]; Note, Federal Regulation of the Going Private Phenomenon, 6 Cum.SAM. L. Rev. 141 (1975); Note, Going Private, 84 YALE L.J. 903 (1975) [hereinafter cited as Going Private].

4. The typical factual situation in "going private" transactions was described by the Chancery Court in the Singer litigation as follows:

[A] private corporation [goes] public, [sells] stock and receive[s] necded capital thereby. The original stockholders [retain] controlling interests. Later, after some degree of prosperity, but at a time when depressed market conditions [cause] the stock to be worth considerably less than the price for which it originally sold, the majority, through formation of a shell corporation, [cause] the corporation to be merged with the majority's wholly-owned "shell," with the minority shareholders being thereby paid off and eliminated for a cash price substantially less than the cost of their initial investment.

Singer v. Magnavox Co., 367 A.2d 1349, 1358 (Del. Ch. 1976), rev'd, 380 A.2d 969 (Del. 1977). Although "going private" is largely viewed as a responsc to a depressed stock market, with controlling insiders taking advantage of the low price/earnings ratio and multiples of book value at which their corporation's stock is then being traded or sold, there is no necessary connection between a bear market and "going private." See, e.g., Bryan v. Brock \& Blevins Co., 490 F.2d 563 (5th Cir.), cert. denied, 419 U.S. 844 (1974). 
Although in a "going private" transaction, a freezeout merger is used only to effect an internal rearrangement of the equity ownership of a single enterprise, ${ }^{5}$ such a merger can also be employed to combine more than one enterprise, either in the context of a preexisting parent and subsidiary ${ }^{6}$ or to complete a corporate acquisition. ${ }^{7}$

Because of the widely recognized permissiveness of corporate regulation of the state level, ${ }^{8}$ with Delaware holding a strong lead in the "race for the bottom," 9 the states were not expected to provide significant protection for minority shareholders involved in freezeout mergers. Rather, it was the nearly unanimous opinion of commentators that any check on freezeout merger abuses would have to come from the federal judiciary on the basis of federal securities regulation law. ${ }^{10}$ In 1977 , however, the Supreme Court held that federal law offers minority shareholders in freezeout mergers only protection from fraud. ${ }^{11}$

Singer's unexpected protection takes on added importance in light of this federal withdrawal. This Note examines Singer, its antecedents and its possible application. It first compares Singer with prior Delaware law, concluding that the judicial imvolvement mandated by Singer represents a significant break with Delaware merger precedent. The Note then analyzes the rules Singer establishes and suggests how they can best be applied in the different types of freezeout merger transactions.

5. See, e.g., Berkowitz v. Power/Mate Corp., 135 N.J. Super. 36, 342 A.2d 566 (Ch. Div. 1975).

6. In the parent-subsidiary context, a cash-out merger is used when the parent organization, having decided to acquire sole ownership of the subsidiary, eliminates the subsidiary's minority public shareholders through a cash-out merger between the parent and the subsidiary, see, e.g., David J. Greene \& Co. v. Dunhill Int'l., Inc., 249 A.2d 427 (Del. Ch. 1968), or between the subsidiary and a shell corporation formed by the parent, see, e.g., David J. Greene \& Co. v. Schenley Indus., Inc. 281 A.2d 30 (Del. Ch. 1971).

7. In the corporate acquisition context, an acquiring corporation, having purchased the controlling interests in a target enterprise, completes its acquisition by using the freezeout device to eliminate the remaining shareholders in the target. See, e.g., Stauffer v. Standard Brands, Inc., 40 Del. Ch. 202, 178 A.2d 311 (Ch.), aff'd, 41 Del. Ch. 7, 187 A.2d 78 (Sup. Ct. 1962). This was the situation in Singer. See text accompanying note 40 infra.

8. For a bibliography of legal commentary noting the inadequacy of state incorporation laws as instruments of corporate regulation, see Jennings, supra note 3, at 991 n.1.

9. Cary, supra note 3 , at 666.

10. See, e.g., Cary, supra note 3, at 701; Jennings, supra note 3, at 992. Professor Cary, although recognizing the need for protective interpretations of present federal law to offset the "Delaware syndrome," has also called for a "frontal attack" by new federal statutes:

It seems anomalous to jigsaw every kind of corporate dispute into the federal courts through the securities acts as they are presently written. . . . It is absurd that a corporate transaction, clearly unfair though perhaps not fraudulent, should be subject to attack in the federal courts only on the ground that it has not been disclosed to the shareholders rather than because of its inherent inequity.

Cary, supra note 3, at 700. But cf. Kert, Going Private: Adopting a Corporate Purpose Standard, 3 SEC. REG. L.J. 33 (1975) (new standards are needed, but the state courts should adopt them).

11. See text accompanying notes 33-38 infra. 


\section{THE Treatment of Minority Shareholders under Delaware LaW}

Prior to Singer, the Delaware cases concerning the protections afforded to minority shareholders followed two conflicting lines. ${ }^{12}$ One protects the interests of the minority shareholders from abuse by the majority. The other ignores the same abuses when they occur in the context of a corporate merger. Singer effectively closes the gap between these two lines by extending the concept of a corporate fiduciary obligation to the merger context.

\section{A. The Minority Protection Cases}

The Delaware courts have protected the interests of minority shareholders of Delaware corporations in a broad variety of nonmerger contexts. In one leading case the court reviewed an attempt by majority shareholders to sell the corporation's assets to a holding company in order to eliminate the minority. ${ }^{13}$ The court noted in dictum that although those who hold a majority interest in a corporation are free at any time "to practically desert the corporate venture by selling out its assets" and thereby to frustrate the minority's participation, this freedom does not permit the majority "to sell to themselves in another guise and thereby carry on in the business without their former associates of the minority." Rather, in such a case "equity would doubtless restrain [the sale] regardless of the fairness of the price."14

The Chancery Court reached a similar result in a case where a majority shareholder employed a charter amendment in his attempt to oust the minority. ${ }^{15}$ At a shareholders' meeting convened in the minority shareholder's absence, the majority shareholder enacted a charter amendment to double the number of approved shares. The new shares were issued at an artificially low par value, which drastically diluted the minority shareholder's interest. When the charter amendment was attacked by the minority shareholder, the court denied the majority shareholder's motions for dismissal and summary judgment on the ground that "action by majority shareholders having as its primary purpose the 'freezing out' of a minority interest is actionable without regard to the fairness of the price." 16

The Delaware courts have rebuffed such thinly veiled attempts by majority shareholders to disenfranchise their "associates of the minority" on the basis that majority shareholders owe the minority a fiduciary duty to

12. For a skillful attempt to reconcile the Delaware cases protecting minority intercsts with the Delaware merger cases, see Balotti, The Elimination of the Minority Interests By Mergers Pursuant to Section 251 of the General Corporation Law of Delaware, 1 DEL. J. CoRP. L. 63, 73-77 (1976).

13. Allaun v. Consolidated Oil Co., 16 Del. Ch. 318, 147 A. 257 (Ch. 1929).

14. Id. at $323-24,147 \mathrm{~A}$. at 260 .

15. Bennett v. Breuil Petroleum Corp., 34 Del. Ch. 6, 99 A.2d 236 (Ch. 1953).

16. Id. at $12,99 \mathrm{~A} .2 \mathrm{~d}$ at 239 . 
preserve and protect the minority's interest in the enterprise. In a wide variety of nonmerger contexts, ${ }^{17}$ the courts have thus maintained the integrity of the minority investor's stockholder relationship by imposing high standards of "honesty, good faith and loyal conduct"18 on persons exercising power and control over corporate affairs. Prior to Singer, however, this solicitude for the minority shareholder had generally been muted in corporate merger cases.

\section{B. Delaware Merger Law}

The original Delaware merger statute was enacted in 1899 as part of Delaware's first general corporation law. ${ }^{19}$ The purpose of the statute was to change the common law rule, which permitted a single shareholder to prevent a merger. Its terms provided that the shareholders of the constituent corporations were to receive shares of the surviving corporation; a minority interest could not be cashed out during a merger. In 1937 the Delaware legislature enacted section 253 of the General Corporation Law, the so-called "short-form" merger statute. ${ }^{20}$ This statute permitted a merger between a parent corporation and its subsidiary by a simple resolution of the parent's board of directors. Because the statute applied only to wholly-owned subsidiaries, it too posed no threat of a cash-out of minority interests.

Section 253 was amended in $1957^{21}$ in two important respects. First, the amended statute permitted a short-form merger between a parent and its subsidiary when the parent owned at least ninety percent of the subsidiary. More importantly, the amendment broadened the types of consideration that could be paid the subsidiary's minority shareholders to include "securities, cash or other consideration." The full effect of the 1957 amendments was tested for the first time in Coyne v. Park \& Tilford Distillers Corp. ${ }^{22}$ Plaintiffs, owners of less than five percent of Park \& Tilford, were cashed out by a short-form nierger between Park \& Tilford and its parent, Schenley Industries. In their action to nullify the merger, the plaintiffs argued that

17. See, e.g., Schnell v. Chris-Craft Indus., Inc., 285 A.2d 437 (Del. 1971) (attempt by management to frustrate a proxy contest by dissident minority shareholders by accelerating the date of a shareholders' meeting found to breach majority's fiduciary duty); Petty v. Penntech Papers, Inc., 347 A.2d 140 (Del. Ch. 1975) (breach of this duty found in attempt by management to redeem preferred stock in a selective manner so as to insure its continued control); Condec Corp. v. Lunkenheimer Co., 43 Del. Ch. 353, 230 A.2d 769 (Ch. 1967) (issuance of new stock in order to defeat a minority shareholder's takeover bid constitutes breach of majority's duty, despite the corporation's strict adherence to statutory procedures).

18. Guth v. Loft, Inc., 23 Del. Ch. 255, 268, 5 A.2d 503, 510 (Sup. Ct. 1939).

19. 21 Del. Laws, ch. 273, § 54 (1898-1899) (current version at DEL. CoDE tit. 8, § 251 (1974 \& Supp. 1977)). For a general history of the Delaware merger statutes discussed in this Note, see E. Folk, The Delaware General Corporation Law 318-26, $351-52$ (1972). The statutory and decisional developments in the Delaware merger law are also discussed in Balotti, supra note 12 , at $64-73$.

20. 41 Del. Laws, ch. 131, § 2 (1937) (current version at DEL. CODE tit. 8, § 253 (1974 \& Supp. 1977)).

21. 51 Del. Laws, ch. $121, \S 6$ (1957) (current version at DEL. CODE tit. 8 \& 253 (1974 \& Supp. 1977)).

22. 37 Del. Ch. 558, 146 A.2d 785 (ch. 1958), aff'd, 38 Del. Ch. 514, 154 A.2d 893 (Sup.

Ct. 1959). 
because section 253 was a simple extension of the grant of power to merge found in section 251, the general or "long-form" merger statute, and because section 251 allowed cash to be paid only in lieu of issuing fractional shares in the surviving corporation, the reference to "cash" in the amended short-form statute should likewise apply only to fractional shares. The court rejected this argument, holding that the wording of the statute indicated the legislative intent to allow the freezing out of minority interests in short-form mergers. ${ }^{23}$

The Chancery Court further clarified the import of the 1957 amendments in Stauffer v. Standard Brands, Inc. ${ }^{24}$ Stauffer involved the use of the short-form merger as the final step in the acquisition of Planters Nut and Chocolate Company by Standard Brands. In upholding the cash-out on the strength of Coyne, the court drew a fundamental distinction between the rights of minority shareholders in a long-form merger and their rights in the short-form context. At the time of Stauffer the long-form merger statute still entitled all shareholders of the constituent corporations to continued participation in the ongoing enterprise. ${ }^{25}$ The terms of long-form mergers would therefore state the ratio at which shares of the constituent corporations would be exchanged for shares or other securities of the surviving corporation. In order to protect the right to continued participation, the court would carefully examine this exchange ratio to insure that shareholders were not coerced by a grossly unfair ratio into electing their appraisal rights. As Stauffer pointed out, however, the minority shareholders in a subsidiary of which the parent owns ninety per cent or more were no longer entitled to continued participation in the enterprise. As a result, the courts no longer needed to scrutinize the adequacy of the proffered consideration in a challenge to a short-form merger because the threat of an improper "appraisaltriggering" 26 was irrelevant. Only the cash value of the minority's invest-

23. 37 Del. Ch. at 564,146 A.2d at 788. Plaintiffs also attacked the cash-out merger on constitutional grounds, arguing that because they had acquired their shares prior to the 1957 amendment they held a "vested right to prevent the conversion of their stock interest into some other form pursuant to authority thereafter granted the corporation." Id. at 565, $146 \mathrm{A.2d}$ at 789. The Chancery Court rejected this argument, holding that a mere conversion, as opposed to a confiscation, of plaintiffs' interests was constitutional. Id.

24. 40 Del. Ch. 202, 178 A.2d 311 (Ch.), aff'd, 41 Del. Ch. 7, 187 A.2d 78 (Sup. Ct. 1962).

25. The long-form merger statute, section 251 , was amended in 1941 to allow the conversion of shares of the constituent corporations into either shares of stock or other securities of the resulting or surviving corporations. 43 Del. Laws, ch. 132, (1941) (current version at DEL CODE tit. 8, § 251 (1974 \& Supp. 1977)). The Delaware Supreme Court had recognized in Coyne that this amendment effectively eliminated the shareholders' immutable right to equity participation in the ongoing enterprise, since redeemable bonds or other debt securities could be paid instead of stock, making the former shareholder a creditor rather than an equity participant in the new enterprise. $38 \mathrm{Del}$. Ch. at 517, $154 \mathrm{~A} .2 \mathrm{~d}$ at 895. The Stauffer court, however, apparently considered the receipt of debt securities to be more similar to equity participation than to receipt of a cash equivalent for purposes of its analysis.

26. See Vorenberg, Exclusiveness of the Dissenting Stockholder's Appraisal Right, 77 HARV. L. REV. 1189,1213 \& n.78 (1964). 
ment was protected in a short-form merger and, at least theoretically, the statutory appraisal proceeding protected that interest. In short, the Stauffer court concluded that when the minority's right to continued participation in the merged enterprise was abolished, the appraisal proceeding became the exclusive remedy for dissatisfied minority shareholders.

The significance of these earlier developments in the short-form statute increased greatly when in 1967 the Delaware legislature amended the longform merger statute to allow cash as well as stock or other securities of the surviving corporation to be paid to shareholders of the constituent corporations. ${ }^{27}$ This amendment made the consideration allowed in long-form mergers roughly identical to that previously authorized for short-form mergers. Not surprisingly, perhaps, in light of the earlier holdings in Coyne and Stauffer, the Delaware courts construed the amended section 251 as they had section 253 , even though this construction gave a bare fifty-one percent majority ownership an absolute right to freeze out the remaining forty-nine percent ownership interests. Thus, the Chancery Court held that the "rights of . . . minority shareholders . . . are no greater under [section 251] than under the so-called short merger statute," and that if the cashed-out minority shareholders "are not satisfied with the value placed on their shares by [the survivor], and no fraud or blatant overreaching is demonstrated, their recourse is to an appraisal." 28

The Delaware courts thus read the amendments to the merger statutes as having abolished the "traditional notions of the immutability of the stockholder relationship," 29 and adopted a "hands off" attitude toward corporate mergers, relegating dissatisfied shareholders in almost all instances to the statutory appraisal remedy. Mergers were thus specially exempted from the court's earlier pronouncement in the minority protection cases that any "action by majority stockholders having as its primary purpose the 'freezing out' of a minority interest is actionable without regard to the fairness of the price." 30

\section{The Growing Discontent with Unregulated Freezeout Mergers}

The gradual development toward unchecked freezeout mergers apparently reflected a belief that utmost flexibility was needed in traditional corporate takeovers and combinations found in parent-subsidiary and corpo-

27. 56 Del. Laws, ch. 50 (1967) (current version at DeL CoDE tit. 8, § 251 (1974 \& Supp. 1977)). The long-form merger statute was amended again in 1968 and 1969 to expand the permissible consideration to include property, rights and securities of any other corporation. 56 Del. Laws, ch. 186, § 16 (1968); 57 Del. Laws, ch. 148, § 22 (1969). Mergers under § 251 require a resolution of the board of directors of each merging corporation and ratification by simple majority vote of the shareholders of the constituent corporations at a meeting for which at least 20 days notice is given. Del. CODE tit. 8, § 251 (1974 \& Supp. 1977).

28. David J. Greene \& Co. v. Schenley Indus., Inc., 281 A.2d 30, 35 (Del. Ch. 1971) (citing Stauffer).

29. Vorenberg, supra note 26 , at 1201.

30. Bennett v. Breuil Petroleum Corp., 34 Del. Ch. 6, 38, 99 A.2d 236, 239 (Ch. 1953). 
rate acquisition contexts. Little concern was shown for the minority shareholders caught in these freezeout transactions because of the assumption that certain benefits naturally arise from these types of freezeouts and that these benefits sufficiently justify the involuntary termination of the minority's interests. As stated in one leading article: "a parent can often avoid business difficulties and generate economies of operation by merging a subsidiary into it, and the purchaser of the vast majority of a company's stock, acquired through a tender offer, for example, can gain needed managerial or structural flexibility by forcing out remaining public shareholders." 31 The emergence of the "going private" type of freezeout merger, in which these usual justifications are lacking, effectively demonstrated the danger of the unlimited license earlier granted to freezeout merger transactions. As a result, commentators began to urge that the power to employ the freezeout merger device should not be absolute, but rather should depend upon a preliminary showing of a valid business purpose for the merger.

The growing recognition of the inadequacy of the statutory appraisal remedy also fueled the freezeout merger controversy. As one leading scholar explained: appraisal is "technical . . . expensive . . . uncertain in result, and, in the case of a publicly held corporation, is unlikely to produce a better result than could have been obtained on the market. . . . It is, in short, a remedy of desperation. . . ."32

These deficiencies of state law became more critical when the Supreme Court refused to expand section 10 of the Securities Exchange $\mathrm{Act}^{33}$ and Securities Exchange Commission rule $10 \mathrm{~b}-5^{34}$ to provide broad regulation of freezeout mergers. After an uncertain beginning, ${ }^{35}$ it had appeared that the federal courts would grant substantial protection to minority shareholders involved in such mergers. In Green v. Santa $\mathrm{Fe}$ Industries, Inc. ${ }^{36}$ and

31. Going Private, supra note 3 , at 921 .

32. Eisenberg, The Legal Roles of Shareholders and Management in Modern Corporate Decisionmaking, 57 CALIF. L. REv. 1, 85 (1969). See also Brudney \& Chirelstein, Fair Shares in Corporate Mergers and Takeovers, 88 HARv. L. REv. 297, 304-07 (1974); Manning, The Shareholder's Appraisal Remedy: An Essay for Frank Coker, 72 YALE L.J. 223 (1962); Vorenberg, supra note 26 , at $1200-05$.

33. 15 U.S.C. $\$ 781(1970)$.

34. 17 C.F.R. $\$ 240.10 b-5$ (1977).

35. Compare Schoenbaum v. Firstbrook, 405 F.2d 200, rev'd en banc on other grounds, 405 F.2d 215 (2d Cir. 1968), cert. denied, 395 U.S. 906 (1969) (grossly unfair transaction accomplished through the "controlling influence" of majority stockholder constitutes fraud under rule 10b-5, even absent misrepresentation or nondisclosure) and Schlick v. Penn-Dixie Cement Corp., 507 F.2d 374 (2d Cir. 1974), cert. denied, 421 U.S. 976 (1975) (parent's manipulation of subsidiary's business prior to freezeout merger, designed to reduce the value of minority's shares in subsequent appraisal proceeding, held violative of rule $10 \mathrm{~b}-5$ even though no votes of minority shareholders needed to accomplish the merger) with Popkin v. Bishop, 464 F.2d 714 ( $2 \mathrm{~d}$ Cir. 1972) (if full disclosure is made in proxy statement, the allegation of an unfair merger rato set by the controlling stockholder does not state a cause of action under rule 10b-5).

36. 533 F.2d 1283 (2d Cir.), rehearing en banc denied, 533 F.2d 1309 (2d Cir. 1976), rev'd, 430 U.S. 462 (1977). 
Marshel v. AFW Fabric Corp. ${ }^{37}$ the Second Circuit significantly broadened the scope of rule $10 \mathrm{~b}-5$ by imposing a "justifiable business purpose" requirement on freezeout mergers, regardless of the extent to which the controlling majority disclosed its selfish purpose. The Supreme Court, however, reversed. In Santa Fe Industries, Inc. v. Green, ${ }^{38}$ the Court determined that section 10(b) and rule 10b-5 could not be extended to impose a business purpose requirement in freezeout mergers as a federal fiduciary duty. The Court held that no federal relief would be granted to minority shareholders who had been displaced in a Delaware "short-form" merger unless nondisclosure, misrepresentation, or manipulation by the majority was shown. Absent such practices, minority shareholders were relegated to the state courts for relief.

The growing critical commentary on "going private" abuses, the open criticism of the appraisal remedy, and the withdrawal of a federal forum thus created pressure on the states to take steps against unjustified freezeout mergers in order to forestall possibly stricter measures from other sources. ${ }^{39}$ It was in this setting that the Delaware Supreme Court addressed the freezeout merger attacked in Singer.

II

\section{THE SINGER CASE}

North American Philips Corporation (North American), the American subsidiary of Philips, the Dutch-based electronics giant, set out to acquire all shares of Magnavox Corporation. Both North American and Magnavox were incorporated in Delaware. North American organized the North American Philips Development Corporation (Development) for the sole purpose of making a tender offer to Magnavox and its shareholders. In August 1974 Development tendered for all of Magnavox's common stock at eight dollars per share, informing Magnavox's shareholders of North American's intention to acquire the entire equity interest in Magnavox. The board of directors of Magnavox notified its shareholders of its opposition to this offer. In September 1974, however, Development made an offer the Magnavox board found more acceptable. The price per share was mine dollars, and North American agreed to two year employment contracts with sixteen of Magnavox's officers, three of whom were also members of the board. The three directors also received options to purchase 5000 shares of

37. 533 F.2d 1277 ( $2 \mathrm{~d}$ Cir.), rehearing en banc denied, 533 F.2d 1309 ( $2 \mathrm{~d}$ Cir.), vacated and remanded for a determination of mootness, 429 U.S. 881 (1976).

38. 430 U.S. 462 (1977).

39. The SEC has recently published a rule proposal relating to "going private" transactions by public companies or their affiliates. See SEC Securities Act Release No. 5884 (Nov. 17,1977 ). If adopted, the proposed rule would provide both disclosure and substantive regulatory protections against "going private" transactions. The SEC report uses the term "going private" in its broadest sense, which includes all three types of freezeout transactions described in this Note. See notes 4,6 and 7 supra. 
North American common stock, effective on the date of the merger. Magnavox's board recommended to its shareholders that this offer be accepted, and Development subsequently acquired $84.1 \%$ of the equity in Magnavox. Once in control of Magnavox, North American moved into the next phase of its staged corporate takeover-the cash-out merger. First a "dummy" corporation, T.M.C. Development Corporation, was set up; a merger between Magnavox and T.M.C. was then arranged, in which the remaining public shareholders in Magnavox were to receive cash rather than shares of stock in the "resulting" corporation. ${ }^{40}$

The plaintiffs, mimority shareholders in Magnavox, sued to nullify the transaction, arguing that the merger constituted common law fraud because it served no valid business purpose and was intended only to deprive them of their equity position in the company. ${ }^{41}$ In rejecting the plaintiffs' clain and dismissing the suit, the Chancery Court found that neither the legislative nor the judicial history of Delaware's merger statutes indicated that a "proper and independent business purpose" was required to eliminate the minority interests in a merger and that in any event plaintiffs' exclusive remedy was the appraisal proceeding. ${ }^{42}$

The Delaware Supreme Court reversed the lower court's ruling on a limited basis. ${ }^{43}$ The court agreed that a merger effected solely to eliminate the minority does not constitute common law fraud, but held that such a inerger does violate a fiduciary duty of the majority shareholder to preserve and protect the minority's interests in the enterprise. Reasoning from the nonmerger cases, which had limited the power of majority shareholders, the court held that "use of corporate power solely to eliminate the minority is a violation of [the majority's fiduciary] duty." 44 The court added to the "valid business purpose" requirement another constraint on the freezeout transaction; the inajority must also satisfy a "faimess" test by convincing the court that the minority shareholders displaced by an otherwise permissible cash-out merger are being treated fairly in the entire transaction. ${ }^{45}$

The Singer court attempted to distinguish the adverse authority of the merger cases. For example, the court read Stauffer as not involving "a

40. Singer v. Magnavox Co., 380 A.2d 969, 971-72 (Del. 1977).

41. Three causes of action were actually asserted before the Delaware Chancery Court. In addition to the common law fraud claim, plaintiffs alleged that by approving the merger with terms known to be grossly unfair to the minority shareholders defendants breached the fiduciary duty owed by the majority to the minority. Finally, plaintiffs alleged that the merger violated antifraud provisions of the Delaware Securities Act, DEL. CODE tit. 6, $\$ \$ 7300-7328$ (1974). 367 A.2d at 1353.

42. 367 A.2d at 1357, 1362. The Delaware appraisal statute is DeL. CODE tit. 8, \& 262 (1974 \& Supp. 1977).

43. The Delaware Supreme Court affirmed the lower court's ruling in regard to plaintiffs' claim under the Delaware Securities Act, though on jurisdictional grounds only. $380 \mathrm{~A} .2 \mathrm{~d}$ at 980-82.

44. $380 \mathrm{~A} .2 \mathrm{~d}$ at 980 (emphasis in original).

45. Id. 
merger in which the minority was expelled via a straight 'cash-for-stock' conversion in which the only purpose of the merger was, as alleged here, to eliminate the minority." 46 The court argued that Stauffer involved "nothing but a difference of opinion as to [the] value"' of the minority's shares, which was properly relegated to an appraisal proceeding. ${ }^{47}$ This distimction is rather facile, however, because the facts of Stauffer and Singer are quite similar. In both an acquirmg corporation in its role as controlling majority shareholder in the target enterprise openly utilized the Delaware merger device to complete its acquisition of the target by eliminating the target's remaining public shareholders.

Singer is thus a departure from the established Delaware rule of judicial noninterference in mergers. ${ }^{48}$ In transferring the corporate fiduciary obligation from the minority protection cases to the Delaware long-form merger statute, Singer effectively ends the former "hands off" posture of the Delaware courts toward mergers. As the Singer court observed: "if it is alleged that the [freezeout] purpose is improper because of the fiduciary obligation owed to the minority, the Court is duty-bound to closely examine that allegation even when all of the relevant statutory formalities have been satisfied." 49

The holding in Singer, however, is limited. It does establish a simple rule of pleading for the plaintiff in freezeout merger cases. ${ }^{50}$ But although

46. Id. at 978 .

47. Id.

48. The Singer court did admit to overruling "inconsistent statements" in two Delaware merger cases, David J. Greene \& Co. v. Schenley Indus., Inc., 281 A.2d 30 (Del. Ch. 1971) (minority's rights in long-form freezeout merger no greater than in short-form context; absent fraud, exclusive remedy is appraisal) and Bruce v. E.L. Bruce Co., 40 Del. Ch. 80, 174 A.2d 29 (Ch. 1961) (judicial interference inappropriate in most merger cases because appraisal remedy is available). 980 A.2d at 979.

In addition, when later discussing the nonexclusiveness of the appraisal remedy for minority shareholders in freezeout mergers, the court did acknowledge an outright inconsistency with the principles voiced in Stauffer, noting that "[a]ny statement in Stauffer inconsistent herewith is held inapplicable to a [section] 251 merger." Id. at 980.

This express limitation by the Supreme Court of the "purpose" and "fairness" tests to long-form mergers was overcome by the Chancery Court in Kemp v. Angel, No. 5442, 1977 (Del. Ch. Dec. 7, 1977). In Kemp the court applied the principles of Singer in granting a preliminary injunction against a short-form merger that was alleged to have no purpose other than the elimination of the minority shareholders. It remains of course to be seen whether this extension of Singer's fiduciary standards to the short-form context will be upheld by the Delaware Supreme Court, or whether that court will refuse to impose these additional transactional burdens on short-form mergers in light of the more limited nature (i.e. never more than ten percent) of the minority freezeout in these transactions.

49. 980 A.2d at 979 .

50. Prior to the Singer decision, a complaint alleging a deliberate cash-out of minority interests was generally vulnerable to a motion to dismiss for failure to state a cause of action. This resulted from the developments in the merger law discussed in this Note, see text accompanying notes 19-30 supra, and also from the general principles established in the following cases: MacCrone v. American Capital Corp., 51 F. Supp. 462 (D. Del. 1943) (the reasons for a merger or the business necessity behind the merger are not matters for judicial determination); Bruce v. E.L. Bruce Co., 40 Del. Ch. 80, 174 A.2d 29 (Ch. 1961) (judicial 
Singer mandates judicial involvement when an unfair freezeout merger is alleged, the extent to which such involvement will substantively protect minority shareholders depends on exactly what fiduciary responsibilities are imposed on majority shareholders, how "fair treatment" for the cashed-out minority is defined, and what remedies the Delaware courts are willing to provide. If the Delaware courts construe the majority's obligation to the minority narrowly, the Singer decision will have little substantive impact. To determine the practical effect of Singer it is therefore necessary to explore the issues left open by the Singer decision.

\section{III}

\section{THE APPLICATION OF SINGER's TESTS}

By combining a "purpose" requirement with a "fairness" test, the Delaware court adopted a two-step analysis. First the majority shareholders must demonstrate a valid reason for the cash-out. Then they must convince the court that the cashed-out minority are being treated fairly in the entire process.

\section{A. The Purpose Test}

Although the Singer court noted that the fiduciary standard for longform freezeout mergers is violated unless a "valid business purpose" for the freezeout exists, it nevertheless postponed analysis of the "business purpose" test. ${ }^{51}$ Tanzer $v$. International General Industries, Inc., 52 decided less than one month after Singer, clarifies the scope of this requirement to some extent. In Tanzer the defendant corporation (IGI) owned eighty-one percent of Kliklok Corporation's outstanding common stock. IGI had devised a plan under which it would acquire the remaining shares through a cash-out merger of Kliklok with KLK Corporation, a dummy corporation formed by IGI as part of its merger plan. Under the terms of the merger, IGI (through $\mathrm{KLK}$ ) would acquire all of the Kliklok stock and the minority stockholders of Kliklok would be paid eleven dollars per share. ${ }^{53}$ Minority stockholders sought a preliminary injunction against the proposed merger. The parties apparently stipulated ${ }^{54}$ that the motivation behind IGI's merger

interference is inappropriate in most merger cases because of the availability of the appraisal remedy); MacFarlane v. North American Cement Corp., 16 Del. Ch. 172, 157 A. 396 (Ch. 1928) (absent a showing of fraud or grossly unfair terms, mergers are encouraged by Delaware public policy). Singer of course overturns all of these earlier principles and establishes that any complaint alleging that the sole purpose of a merger is to eliminate the minority is sufficient to withstand a motion to dismiss.

51. 380 A.2d at 980, n.11.

52. No. 24, 1976 (Del. Oct. 18, 1977).

53. Id., slip op. at 4-5.

54. Although the lower court apparently included in its findings of fact a determination that IGI had a "legitimate and present and compelling business reason" to effect the challenged merger, it does not appear that the plaintiffs disputed the presence of this reason. Their 
plan was to facilitate IGI's long-term debt financing, which required IGI to be the sole owner of its subsidiary. ${ }^{55}$ The plaintiffs argued that the merger should be enjoined under Singer because the merger served only the interests of the parent and in no way advanced the business of the subsidiary. The Delaware Supreme Court rejected this argument and held that IGI's fiduciary duty did not require it to "sacrifice its own interest in dealing with a subsidiary; "but that interest must not be suspect as a subterfuge, the real purpose of which is to rid itself of unwanted minority shareholders in the subsidiary." 56

Tanzer's bona fide purpose test emerges as a more permissive standard for freezeout mergers than the valid business purpose test as typically defined in the cases and commentary. Under Tanzer any bona fide motive of the parent, however selfish, can nevertheless justify cashing out the minority shareholders in the subsidiary. Thus the bona fide purpose test requires no benefit to accrue directly to the enterprise from which the minority shareholders are displaced. In contrast, the commonly accepted notion of the valid business purpose test assumes that the minority shareholders should suffer forced displacement from an enterprise only when their removal serves the interests of that enterprise. ${ }^{57}$ In short, the bona fide purpose test is more permissive than the valid business purpose test because, although a valid business purpose is necessary to justify the cash-out merger, any valid business purpose will do.

The Tanzer test is more lenient than the valid business purpose test, however, only when the majority shareholder is itself a business or functioning enterprise. A separate functioning entity is present in the parent-subsidiary and corporate acquisition contexts, and hence most freezeout mergers in these contexts will probably pass muster under the bona fide purpose test. ${ }^{58}$ In "going private" transactions, however, the interests of a separate functioning enterprise are never at stake. Hence the bona fide purpose test applied to these transactions should make the same demands on the controlling insiders as the valid business purpose test: the termination of

complaint was premised instead on the argument that the freezeout merger was illegal because the business reason for it stemmed from the need of the parent, but not from any need of the subsidiary.

55. Slip op. at 11 .

56. Id. at 10 .

57. See, e.g., Business Purpose Test, supra note 3, at 1207-11.

58. One writer has compiled the following list of justifications typically present in the parent-subsidiary and corporate acquisition contexts:

Elimination saves the cost of supplying information under federal and state law about the subsidiary to the minority stockholders; it avoids questions of conflict of interest and usurpation of corporate opportunity; it removes the threat to [the parent] of litigation by minority stockholders over judgments made by [the dominated subsidiary's] management with respect to such policy matters as dividends, expansion of business, or allocation of intercorporate expense; it creates tax advantages; and it may lead to certain economies by reason of the combined operations of the two companies.

Greene, Corporate Freeze-out Mergers: A Proposed Analysis, 28 STAN. L. REv. 487, 494 (1976). 
the minority's equity interests will not be allowed unless an interest of the enterprise in which they share ownership is served by the elimination of that partial ownership.

The Delaware Supreme Court has never confronted a "going private" type of freezeout merger. Given this interpretation of the bona fide purpose test, however, one can expect that majority shareholders in typical "going private" transactions will encounter some difficulty in proving a legitimate business need to eliminate the minority's equity participation. Unlike parent-subsidiary and corporate acquisition freezeouts, the "going private" transaction admits of no obvious or typical benefits flowing from the cashout merger. The business purposes typically offered to support "going private" transactions have been carefully scrutinized, and usually dismissed by commentators, so that few conceivably valid reasons are left standing..$^{59}$ Many "going private" attempts may therefore find the bona fide purpose test an insurmountable obstacle.

The Singer court did not specify the relief available when the majority fails to satisfy its two-tier test, but noted that such relief would be granted "as equity may require." 60 If the majority shareholder atteinpting a freezeout merger fails to satisfy the first-tier bona fide purpose test it would seem that an injunction against the merger should issue. ${ }^{61}$ In such a situation the elimination of the minority shareholders from the enterprise is, by definition, unjustified and should therefore be prohibited.

\section{B. The "Entire Fairness" Test}

Singer added a second tier to the majority's ficuciary duty by holding

59. For a thorough discussion of possible corporate motives in "going private" and the relative merits thereof, see Brudney, supra note 3, 1031-39; Business Purpose Test, supra note 3 , at $1207-11$.

One commentator has argued that the "going private" type of freezeout transaction contains sufficiently high risks of abuse by majority shareholders to warrant the complete prohibition of this type of corporate freezeout. See Greene, supra note 58, at 512-13.

A valid business purpose for "going private" was found by the court in Grimes v. Donaldson, Lufkin \& Jenrette, Inc., 392 F. Supp. 1393 (N.D. Fla. 1974), aff'd mem., 521 F.2d 812 (5th Cir. 1975). The facts of this case, however, reveal that this "going private" transaction actually more closely resembles the corporate acquisition type of freezeout transaction: one corporation gradually acquired a controlling interest in another corporation engaged in the same business. The dominant corporation then attempted a freezeout merger between the two enterprises in order both to avoid conflict of interest problems and to achieve economies of operation.

60. 380 A.2d at 980 .

61. The first step for minority shareholders challenging a freezeout merger should be to seek a preliminary injunction against the merger pending a determination of the "purpose" question, so that the court would not later be faced with the inherently untenable task of undoing a freezeout merger, however "purposeless" the freezeout may have been. See, e.g., Kemp v. Angel, No. 5442, 1977 (Del. Ch. Dec. 7, 1977).

The related issue of "fairness" could also be raised and resolved at the same postpreliminary injunction hearing, although fairness test violations would usually not involve the extraordinary injunctive relief called for by violations of the "purpose" test, see note 72 infra and accompanying text. 
that, "business purpose" notwithstanding, the majority's treatment of the minority in the freezeout transaction must meet a test of "entire fairness." The Singer court resurrected this "entire fairness" test from Sterling $v$. Mayflower Hotel Corp., ${ }^{63}$ a leading "interested merger" case. Recognizing that the terms of a merger between a parent and its dominated subsidiary are necessarily determined unilaterally by the parent rather than through arm'slength negotiations, Sterling held that since the parent stands "on both sides of the transaction, [it must] bear the burden of establishing its entire fairness, and [the transaction] must pass the test of careful scrutiny by the courts." 64

Singer's extension of the Sterling fairness test to freezeout mergers indicates the Delaware court's recognition of the inadequacy of the appraisal remedy. ${ }^{65}$ Before Singer minority shareholders were automatically relegated to the appraisal proceeding unless they could establish that the merger should be enjoined. ${ }^{66}$ But after Singer minority shareholders are entitled to a fairness hearing even if the minority freezeout is justified so that the merger itself may continue. ${ }^{67}$ Because the issue of fairness will usually turn on whether the amount to be paid the minority shareholders is adequate or has otherwise been "tainted" by unfair acts of the majority shareholder, the fairness hearing will in effect replace and enlarge the appraisal proceeding in freezeout merger transactions. ${ }^{68}$

62. 380 A.2d at 980 .

63. 33 Del. Ch. 293, 93 A.2d 107 (Sup. Ct. 1952).

64. Id. at 298,93 A.2d at 110 . The Sterling rule of "entire fairness" had actually lost much of its vitality, if indeed it ever had any, with the subsequent developments in the Delaware merger law eroding the minority's immutable status as equity investors and making appraisal the exclusive remedy. Along these lines one can more readily comprehend the import of the vice chancellor's dictum in Stauffer v. Standard Brands, Inc., 40 Del. Ch. 202, 178 A.2d 311 (Ch.), aff'd, 41 Del. Ch. 7, 187 A.2d 78 (Sup. Ct. 1962), that under the general merger statute the majority are not permitted to force the minority to accept a "gross undervaluation" which may be "shocking to the court's conscience and, therefore, constructively fraudulent." 40 Del. Ch. at 208, 178 A.2d at 314. The "entire fairness" test of Sterling became in effect a "gross unfairness" test with a burden of proof no doubt easily met by any majority. See, e.g., Bastian v. Bourns, Inc., 256 A.2d 680 (Del. Ch. 1969), aff'd, 278 A.2d 467 (Del. 1970).

65. The Singer court cited Vorenberg, supra note 26 , while pointedly remarking that the "defendants cannot meet their fiduciary obligations to plaintiffs simply by relegating them to a statutory appraisal proceeding." 380 A.2d at 977.

66. David J. Greene \& Co. v. Schenley Indus., Inc., 281 A.2d 30, 35 (Del. Ch. 1971).

67. This was the disposition of Tanzer. The court found a bona fide purpose for the freezeout merger and affirmed the order denying injunctive relief, but it remanded the case to the lower court for a fairness hearing. Slip op. at 12.

68. The appraisal alternative under $\$ 262$ of the Delaware General Corporation Law will of course remain available but because of the burden of proof advantages of the Singer fairness hearing and the generally recognized inadequacy of the appraisal remedy, see note 32 supra and accompanying text, it seems doubtful that minority shareholders will prefer the appraisal proceeding to the fairness hearing. For a discussion of the possibility that the fairness hearing could be used as a sort of "super-appraisal" remedy for the minority shareholders seeking adequate compensation for the loss of their equity participation, see text accompanying notes 74 to 85 infra. 
The fairness test Singer mandates is comprehensive in scope. Tanzer clearly indicates that the inquiry should not be limited to considerations of the stock's price. ${ }^{69}$ Rather, the courts should examine all facets of the transactions leading up to and including the cash-out merger to determine if the minority shareholders have been treated fairly. In his concurring opinion in Singer, Justice McNeilly argued that the fairness scrutiny should include "the business purpose, or economic necessity, desirability and feasibility involved, evidence of self-serving, manipulation, or overreaching, and all other relevant factors of intrinsic fairness or unfairness."70 The wideranging inquiry of the fairness hearing should thus encompass such matters as side payments to management, ${ }^{71}$ seizure of corporate opportunities, or manipulation by the parent that depressed the value of the subsidiary's business prior to the cash-out.

Evidence of overreaching or self-serving by the majority should justify an injunction against the merger only in the extraordinary situation where the freezeout transaction is so thoroughly tainted by the majority's acts as to defy adequate correction through damages. ${ }^{72}$ More typically, the minority will be adequately compensated if indications of such manipulation or fraud are considered in evaluating the adequacy of the compensation offered them.

69. The Delaware Supreme Court in Tanzer chided the lower court for adopting a restrictive approach when reviewing the cash-out price:

The Chancellor's opinion, announced at the preliminary injunction stage of this proceeding, discussed fairness only in terms of the price offered for the stock, but that was too restrictive. The test required by Singer, which applied the rule of Sterling, involves judicial scrutiny for "entire fairness" as to all aspects of the transaction.

Slip op. at 12.

70. 380 A.2d at 982 .

71. The problem of "side payments" in freezeout transactions is discussed in Brudney \& Chirelstein, supra note 32 , at 340-44. This problem appears to be particularly applicable to the Singer facts. Equality of treatment had been superficially provided for the cashed-out minority shareholders of Magnavox, since the per share price offered them was equal to that paid for the controlling interests. But Singer also involved possible side payments. After employment contracts and stock options were offered to certain members of Magnavox management, opposition to the takeover was withdrawn. See text accompanying note 40 supra. In relation to this type of self-serving, Professors Brudney and Chirelstein observed:

When there is reason to suspect that side payments either have induced a target's management to temper opposition to a merger or have constituted part of the premium paid to a seller of control, it is entirely appropriate to make available a challenge to the fairness of a merger price notwithstanding its equivalence to the price paid in a successful tender offer or a negotiated purchase of control.

Brudney \& Chirelstein, supra note 32, at 341 (emphasis added). Brudney and Chirelstein go on, however, to note the inherent problems of proof in establishing the link between such side payments and the controlling interest purchase.

72. This assumes that the minority challengers have raised the "fairness" issue in time for the court to grant injunctive relief, such as at a hearing pursuant to a preliminary injunction, see note 61 infra. The court in Tanzer, for instance, noted that the freezeout merger under review had already been consummated. Slip op. at 5 . This fact, together with the apparent absence of any flagrant "fairness" violations, no doubt influenced that court's denial of injunctive relief prior to the complete resolution of the "fairness" issue. 
Awarding damages or an injunction for fraud or overreaching by the majority is a common practice for courts ${ }^{73}$ and would not by itself require the authority of Singer's new fairness test. The proposed hearing, however, if administered with heightened judicial sensitivity to the intractable valuation conflicts in freezeout mergers, could become a significant new device for assuring that the minority receive adequate compensation for their shares. In fashioning this new remedy, the Delaware courts should revive Sterling's arm's-length standard of valuation as their fairness norm. Such a standard assumes that "a fair price for the minority stock is that which an arm's-length bargain in a free market would have produced." 74 How effectively this fairness norm can be applied depends in turn on whether the freezeout transaction occurs in the context of a corporate acquisition, a parent-subsidiary combination, or a "going private" attempt.

In the corporate acquisition situation, ${ }^{75}$ where remaining public shareholders are displaced through a cash-out merger soon after the acquiring corporation has gained a controlling interest through tender offers, it is generally agreed that the minority is adequately compensated if it receives the tender offer figure that induced the original majority to sell its interests in the enterprise. ${ }^{76}$ Equality of treatment for all original shareholders is thereby insured. Moreover, the tender offer price has the marks of a genuine arm's-length valuation of the minority's investment in the enterprise, since it may have been negotiated and in any event was accepted by the majority of investors in the enterprise. Accepting this figure as satisfying the arm'slength standard does ignore any "special" values that the minority "holdouts" may have attached to their stock, but such values are apparently considered too subjective to be relevant to a reasonably objective valuation of the minority shareholder's investment. ${ }^{77}$

For the parent-subsidiary and "going private" types of freezeout mergers, no straightforward arm's-length valuation of the minority's interests is possible. The proffered cash-out consideration in these situations is necessarily determined unilaterally by the parent's management ${ }^{78}$ without arm's-

73. See, e.g., Sinclair Oil Corp. v. Levien, 280 A.2d 717 (Del. 1971); David J. Greene \& Co. v. Dunhill Int'l., Inc., 249 A.2d 427 (Del. Ch. 1968).

74. Brudney \& Chirelstein, supra note 32 , at 309.

75. This discussion assumes that no side payments or similar manipulation taint the fairness of the tender offer figure.

76. See Brudney, supra note 3, at 1037; Jennings, supra note 3, at 1021.

77. The court might also recognize, however, that accepting this tender offer amount as satisfying the fairness norm deprives the minority of their right to serve as their own bargaining agents in the arm's-length valuation process. The minority's failure to sell their interests for the earlier tender offer amount reasonably indicates that the amount does not satisfy the minority's valuation of their ownership interests. As a result, the court in a fairness hearing could choose to adopt the tender offer figure as a base value for the minority's interest, thereby prodding the new majority to "bid up" its cash-out offer to the minority in order to approximate more closely a "true" arm's-length valuation of the minority's investment.

78. For ease of discussion, reference to the "parent" in this section will also include the displacing insiders of the "going private" transaction, since their role in determining the cashout terms is identical to that of the parent in the parent-subsidiary freezeout merger context. 
length bargaining. ${ }^{79}$ The inherently suspect nature of the cash-out pricesetting mechanism in these transactions presents special problems for a court attempting to determine fair compensatory treatment for the minority. Even if the enterprise is publicly held, resort to the prevailing market price may not provide an adequate fairness standard. Because of the volume of the stock of the enterprise that is traded, the presence of institutional investors, or a general market breakdown, the stock exchange price may not adequately compensate the minority for the true value of their stock. ${ }^{80}$ Fairness of a market value standard in the parent-subsidiary context is even more questionable, because the "prior part ownership of the parent and inhibiting effects thereof generally will have distorted the market value of the public float. The most progressive rules . . . cannot prevent manifold and perhaps nonactionable forms of exploitation of control from inhibiting the function of the market place...."81

One possible approach for a court faced with these twin dilemmas of a controlled price and an uncertain market standard would be the adoption of the postmerger theory of valuation as a reasonable surrogate for the arm'slength valuation standard. ${ }^{82}$ Under this theory, the court would require from the parent a reasonable quantification of the gain it expects to derive from the freezeout merger and sole ownership of the enterprise. This gain would then be shared with the displaced minority shareholders in a cash-out price computed by adding a proportion of the gain to the base value of the minority's investment. ${ }^{83}$ The postmerger theory of valuation would operate nicely, it has been argued, in conjunction with a valid business purpose test. ${ }^{84}$ Unless the parent can demonstrate a substantial, quantifiable gain from acquiring sole ownership of the subsidiary, the court should find no valid business purpose for the freezeout. If substantial benefits flowing from the cash-out are shown, the court can then apply the postmerger standard of valuation and effect whatever adjustment to the cash-out price is necessary to insure that the financial benefits are shared with the displaced minority.

Despite the intrinsically "equitable" appeal of the sharing obligation under the postmerger valuation theory, significant obstacles may block its application by the Delaware courts. The express language of the Delaware

79. This of course was the crux of the rationale behind Sterling's "entire fairness" test and the reason for placing a heavy burden on the majority shareholder in "interested merger" cases to demonstrate that its treatment of the minority shareholders approximates what might have been achieved by the minority had genuine arm's-length bargaining been possible.

80. Buxbaum, The Dissenter's Appraisal Remedy, 23 UCLA L. REv. 1229, 1247 (1976).

81. Id. at 1248 .

82. The original postmerger theory of valuation can be found in Brudney \& Chirelstein, supra note 40 . Although this theory of valuation was originally considered only in relation to parent-subsidiary freezeout mergers, Professor Brudney in a later article applied the same principles to the "going private" context. See Brudney, supra note 3, at 1025.

83. The base value of the minority's investment is apparently to be determined by existing appraisal methods. See Business Purpose Test, supra note 3, at 1219.

84. Id. at 1218 . 
appraisal statute provides that the appraised value of the dissenter's shares is to be "exclusive of any element of value arising from the accomplishment or expectation of the merger." 85 The Delaware courts may not feel comfortable in adopting a valuation standard that so flatly contradicts the expressed will of the legislature. The fairness hearing may be viewed, however, as an alternative to the appraisal remedy and as such not bound by its terms. Neither the bona fide purpose test nor the fairness hearing are required by any Delaware statute. Moreover, if a standard of arm's-length bargaming is to be used, it appears almost irrational to exclude future value from consideration, for any bargain struck through true arm's-length negotiation will necessarily reflect the parties' estimation of what the stock will be worth in the future.

Practical application of the postmerger theory might also prove problematic. It is likely that the "efficiency" gains offered to justify freezeout mergers will often be intangible; to demand rational quantification of such gains from the displacing parent (or the market) may be simply unrealistic. Moreover, application of the postmerger theory depends on the ability to ascertain the value of the enterprise at the time of merger. The growing loss of confidence in the accuracy of sucl external standards as the stock market and existing appraisal methods casts doubt on the ability of the postmerger theory to generate a fair value for the minority's interests.

Even if the postmerger theory of valuation is rejected, the effectiveness of the fairness hearing may not be seriously compromised. For in the final analysis, the concern with establishing an exact valuation formula may be misguided. It should suffice for the courts to acknowledge the inherently suspect nature of both the unilaterally determined cash-out price and the external standards such as market value against which that price might be compared. Because the standard for judging fairness is necessarily unclear, the most likely function of the fairness hearing is that of a judically supervised renegotiation session between the parties. There is of course no assurance that the renegotiated price would equal a true arm's-length valuation of the minority's interests. But such renegotiation could strike a balance between the needs for corporate flexibility and minority protection. Judicial supervision of the process would preserve flexibility by shielding the merger process from the potentially disruptive demands of minority "hold-outs." The minority would be protected in two ways. First, the potential cost of the hearing in terms of both delay and expense may encourage the majority to make a higher initial offer to the minority. Second, the fact that the majority will bear the burden of proving that its offer is fair provides the minority with additional leverage to counteract the inadequacy of traditional methods of valuation.

85. DeL. CoDE tit. 8, § 262(f) (Supp. 1977). 


\section{CONCLUSION}

Singer v. Magnavox Co. reverses the earlier Delaware rule of judicial noninterference in corporate merger transactions. This somewhat unexpected reversal fills at least a portion of the gap left by the recent federal withdrawal from the area.

To protect minority shareholders, the court imposed a two-tier test. First, the majority must prove that a valid business purpose justifies the merger. Because Tanzer permits a majority that is itself a business entity to satisfy this test by proving only that the merger serves its own interests, most corporate acquisition and parent-subsidiary freezeouts will meet this tier of the Singer standard. Since they are undertaken for the sole purpose of eliminating minority public shareholders, however, most "going private" transactions will not.

Mergers that have a bona fide business purpose must meet a second requirement. The entire transaction will be scrutinized to ensure that minority shareholders are being treated fairly. This tier certainly protects the minority from fraud and manipulation by the majority. It might also be employed to impose new tests for the adequacy of consideration. In any event, the minority's ability to compel a hearing provides them with a new bargaining chip in their dealings with the majority, which may serve to counterbalance the inherent inequality of the bargaining relationship. If flexibly administered, the new Singer rules may go far in providing adequate relief for the "victims" of freezeout mergers.

Randolph B. Godshall Douglas L. Hendricks**

* B.A. 1974, Yale University; second-year student, Boalt Hall School of Law.

** B.A. 1975, California State University, Fresno; third-year student, Boalt Hall School of Law; Editor-in-Chief, California Law Review. 